\title{
Nutraceutical fruit characterization, nutritional aspects and sensory analysis of dovyalis jams
}

\section{Maria Cristina Copello Rotili ${ }^{1}$ Fabíola Villa $^{1^{*}}$ Daniel Fernandes da Silva ${ }^{1}$ Solivan Rosanelli ${ }^{1}$ Gilberto Costa Braga ${ }^{1}$ Tatiane Eberling ${ }^{1}$}

${ }^{1}$ Centro de Ciências Agrárias (CCA), Universidade Estadual do Oeste do Paraná (Unioeste), 85960-000, Marechal Cândido Rondon, PR, Brasil. E-mail: fvilla2003@hotmail.com. "Corresponding author.

\begin{abstract}
The objective of this study is to evaluate the composition, nutritional aspects and sensory analysis of the dovyalis jam. Dovyalis fruits were harvested from 4-year-old plants in the orchard of the Unioeste Experimental Farm. They were collected in the morning in polyethylene boxes, when they were ripe and with a purple coloration from the epicarp, being immediately transported to the Laboratory to prepare the jams. After fruits arrival, they were selected by size, color and weight and then sanitized in running water and the cups of the fruits were removed. The sensory evaluations of the jam samples were performed in a randomized fashion, with 30 volunteer tasters. The tasters were previously advised to evaluate the acceptance of the jams and their purchase intentions. Fruits in natura and dovyalis jam are sources of vitamin C. Dovyalis fruits can be used in the processing, due to its acidity. The jam prepared with dovyalis fruits without epicarp and endocarp, and less sugar, was more appreciated by the tasters.
\end{abstract}

Key words: Dovyalis hebecarpa, small fruits, processing, nutritional quality.

\section{Caracterização de um fruto nutracêutico, seu aspecto nutricional e} análise sensorial de geleia

RESUMO: Objetivou-se com o presente trabalho avaliar a composição, aspectos nutricionais e análise sensorial da geleia de dovyalis. Frutos de dovyalis foram colhidos de plantas de quatro anos, no pomar da Fazenda Experimental da Unioeste. Estes, foram coletados de manhã, em caixas de polietileno, quando encontravam-se maduros e com coloração arroxeada do epicarpo, sendo imediatamente após, transportados ao laboratório, para o preparo das geleias. Após a chegada dos frutos, estes foram selecionados por tamanho, coloração e peso e, em seguida, higienizados em água corrente e retirados os cálices dos frutos. As avaliações sensoriais das amostras de geleia foram realizadas de forma casualizada, com 30 provadores voluntários. Os provadores foram previamente orientados a avaliarem a aceitação das geleias e suas intenções de compra. Frutos in natura e geleia de dovyalis são fontes de vitamina C. Frutos de dovyalis podem ser usados no processamento, devido sua acidez. A geleia preparada com frutos de dovyalis sem epicarpo e endocarpo, e menor quantidade de açúcar, foi mais apreciada pelos provadores.

Palavras-chave: Dovyalis hebecarpa, pequenos frutos, processamento, qualidade nutricional.

\section{INTRODUCTION}

Dovyalis is an exotic fruit species belonging to the Salicaceae family. Originally from South India or the Ceylon Island, it has spread all over the world, adapting to the different growing regions, including Brazil (RINALDI et al. 2017; BORGES et al. 2010).

Its fruits are spherical in shape, approximately $2-3 \mathrm{~cm}$ in diameter, juicy pulp, acids and highly perishable, being used mainly in processing, with characteristics favorable to the manufacture of juice, liqueur and jam (ALMEIDA et al. 2011). Fruits, in addition to having phenolic compounds and carotenoids, may also contain vitamin
$\mathrm{C}$ or L-ascorbic acid, which is a widely distributed water-soluble and thermolabile vitamin (JACQUES \& ZAMBIAZI, 2011).

The jam is an important alternative for the processing, use and consumption of fruit. According to CNNPA Resolution No. 12.486, of 1978 (CNNPA, 1978), it is established that fruit jam is the product obtained by cooking fruits, whole or in pieces, pulp or fruit juice, with sugar and water, and concentrated until gelatinous consistency is achieved. Glucose or invert sugar may be added to brighten the product, the addition of acidulants and pectin being tolerated to compensate for any deficiency in the natural pectin or fruit acidity content. Ripe fruits usually have less pectin than unripe ones (CURI et al. 2017). 
Jam is commonly used to accompany bread, cake, biscuits and confectionery. The use of food technology for the manufacture of new products, such as jam, can be a viable alternative for the processing, utilization and consumption of exotic fruits, providing a greater supply and increase of the shelf life, as well as contribute with the value aggregation to the fruit and income generation (OANCEA \& CALIN, 2016).

Food, in addition to its nutritional value, should also produce satisfaction and be pleasing to the consumer's taste as a result of the balance of different parameters of sensory quality (MACIEL et al. 2009). According to Souza et al. (2014) when developing a new product, it is imperative to improve parameters such as shape, color, appearance, odor, taste, texture, consistency and interaction of the different components, with the ultimate goal of achieving an integral balance and; consequently, good quality and acceptability of the product.

Sensory analysis of the jam can be performed in order to verify the acceptance of this product by consumers. This analysis is done using the human senses and cutaneous sensitivity (TEIXEIRA, 2009; PEREIRA et al. 2011). Sensations that result from the interaction of human sensory organs with foods are used to evaluate their quality and acceptability by the consumer, as well as being very useful for the development of new products.

The literature reports little information on formulation, preparation and sensory characteristics of jam from small fruits, mainly dovyalis (CAETANO et al. 2012). In view of the above, the objective of this study is to evaluate the composition, nutritional aspects and sensory analysis of the dovyalis jam.

\section{MATERIALS AND METHODS}

Dovyalis fruits (D. hebecarpa) were harvested from 4-year-old plants in the orchard of the Experimental Farm. The harvested took between 8:00 and 9:00 am and the fruits were arranged in polyethylene boxes, when they were ripe and with a purple coloration from the epicarp, being immediately transported to the Post-Harvest Technology Laboratory to prepare jams.

After the arrival of the fruits at the Laboratory, they were selected by size, color and weight, sanitized in running water and cups of the fruits were removed. Afterwards, the physicalchemical characterization of the fruits and the preparation of the jams were carried out (jam $A=1$ $\mathrm{kg}$ of sugar $+1 \mathrm{~L}$ of water + fruits with epicarp + mesocarp + endocarp and jam B $=800 \mathrm{~g}$ of fruit +500 $\mathrm{mL}$ of water + fruits without endocarp.

For chemical characterization of the fruits, the titratable acidity, $\mathrm{pH}$, soluble solids and vitamin C were analyzed (IAL, 2008). For jams, there were analyzed like the physicochemical characterization the titratable acidity, $\mathrm{pH}$, soluble solids, humidity, reducing sugars and coloration (MAIA et al. 2014).

Color of the jams was determined by a colorimeter of the brand Konica Minolta (Sensy CR 400 model, Osaka, Japão). Ten g of each jam analyzed were placed in a petri dish, and the color was measured in white light at room temperature (RODRIGUES et al. 2020). It was expressed by the rectangular coordinate system $\mathrm{L}^{*}$ (luminance values expressed in percentages, with $0 \%=$ black and $100 \%$ $=$ white), $\mathrm{a}^{*}$ [represents the colors red $(+)$ or green $(-)$ ] and $\mathrm{b}^{*}$ [represents the colors yellow $(+)$ or blue $(-)$ ], according to Comission Internatinale de E'clairage (CAETANO et al. 2011).

The titratable acidity was obtained by titrating $5 \mathrm{~mL}$ of dovyalis juice homogenized and diluted to $10 \mathrm{~mL}$ of distilled water with a standard solution of $1 \mathrm{~N}$ sodium hydroxide, with phenolphthalein as the indicator. Results were expressed as grams of citric acid per $100 \mathrm{~g}$ of pulp ( $\mathrm{g}$ of citric acid $100 \mathrm{~g}^{-1}$ ), according to the methodology described by Instituto Adolfo Lutz (Ial, 2008). The pH was performed with a digital potentiometer. Soluble solids (SS) followed the methodology described by Ial (2008), and results were expressed in ${ }^{\circ}$ Brix.

The vitamin $\mathrm{C}$ or ascorbic acid was determined by titration with 2.6-dichloro-phenolindophenol, as proposed by Benassi \& Antunes (1988). Results were expressed in $\mathrm{mg} 100 \mathrm{~mL}^{-1}$ of juice. The moisture of jams followed the methodology described by Ial (2008), and results are expressed in $\mathrm{g} 100 \mathrm{~g}^{-1}$. The reducing sugars followed the methodology described by Ial (2008), and results are expressed in $\mathrm{g} 100 \mathrm{~g}^{-1}$.

Sensory evaluations of jam samples were randomized by 30 volunteer tasters without previous training, of both genders, different age groups and schooling. The sensory tests were performed in a single day at the Unioeste Post-Harvest Laboratory, using a mixed eight-point hedonic scale, which gradually 8 (extremely like it), 7 (like it a lot), 6 (moderately like it ), 5 (slightly like it), 4 (don't like it/don't dislike it), 3 (slightly dislike it), 2 (dislike it a lot) and 1 (extremely dislike it). The intention of the judges to buy jams was also evaluated using a mixed five-point scale, ranging from 1 (would certainly buy), 2 (would possibly buy it), 3 (might buy it/might 
not buy it), 4 (would possibly not buy it) and 5 (would not buy) the product (MEILGAARD et al. 2007; FERREIRA et al. 2011; OLIVEIRA et al. 2013).

For the sensory tests, jam samples of approximately $10 \mathrm{~g}$ were used, being randomly presented to the tasters at room temperature $\left(22^{\circ} \mathrm{C}\right)$ (KEMP et al. 2009), in plastic cups (50 mL), always accompanied by water and crackers. The samples were made available in order of presentation, in which all consumers evaluated the acceptance of all samples corresponding to jams A and B, following a design of complete balanced blocks.

The judges (tasters) were previously advised to evaluate the acceptance of the jams and their purchase intentions. The statistical evaluation of the results obtained in the sensory test was performed using the statistical program Sisvar (FERREIRA, 2011), through variance analysis (anova) and Tukey's test to compare the averages between the samples, with a $5 \%$ probability of error.

\section{RESULTS AND DISCUSSION}

Table 1 shows the chemical evaluation results for jams $\mathrm{A}$ and $\mathrm{B}$ and fruits in natura. It was found that the $\mathrm{pH}$ was 3.2 , higher than the one in jams A and B, with 2.93 and 2.67, respectively. Acid fruits $(\mathrm{pH}<7.0)$ have desirable characteristics for industrialization, with a high $\mathrm{pH}$ for gel formation when manufacturing the jam of 3.0 to 3.20 (CAETANO et al. 2012). Silva et al. (2011) working with dovyalis cultivar Romana, the $\mathrm{pH}$ values were around 3.0, demonstrating that the fruits are acidic and ideal for processing.

In general, a jam must have $\mathrm{pH}$ between 3.0-4.0 and acidity between $0.3-0.8$ of citric acid (DAMIANI et al. 2012). During processing, degradation of labile nutrients and bioactive compounds (SOUZA et al. 2015), such as vitamins, can occur, thus altering the nutritional composition of foods and compromising the final quality of the product (ZORZI et al. 2020).

For the acidity, jams $\mathrm{A}$ and $\mathrm{B}$ are in agreement with the recommended amount for the manufacture of jams, presenting averages of $0.47 \mathrm{~g}$ citric acid $100 \mathrm{~mL}^{-1}$. The low $\mathrm{pH}$ values reported in the jams are due to the ingredients heating, which go through changes. One of the compounds formed from the sugar is acidic, causing an increase in the acidity of the product. Moreover, with the addition of sugar and heating, there is a reduction of the water content in the medium, concentrating all the jam constituents (MACIEL et al. 2009).

For soluble solids, jam A presented 80 ${ }^{\circ}$ Brix, whereas jam B presented $73^{\circ}$ Brix, the high sugar concentrations is due to the addition of commercial sugar in the processing of both jams, since sugar acts as a preservative and its high content in food inhibits microbial growth improving its appearance, flavor and yield (SANTOS et al. 2013). Therefore, the final concentration of SS for jam varies depending on the production process and ingredients used.

High values of ascorbic acid (or vitamin C) were observed in the two jams prepared, but a

Table 1 - Chemical evaluations of jams A and B and in natura dovyalis fruit and physical-chemical evaluations of dovyalis jams A and B.

\begin{tabular}{|c|c|c|}
\hline \multirow[t]{2}{*}{ Chemical evaluations } & \multicolumn{2}{|c|}{ 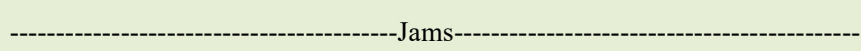 } \\
\hline & A & B \\
\hline $\mathrm{pH}$ & $2.93 \pm 0.19$ & $2.67 \pm 0.07$ \\
\hline Soluble solids ( ${ }^{\circ}$ Brix $)$ & $80.0 \pm 0.82$ & $73.0 \pm 0.82$ \\
\hline Acidity (g citric acid $100 \mathrm{~mL}^{-1}$ ) & $0.47 \pm 0.19$ & $0.47 \pm 0.19$ \\
\hline \multirow[t]{2}{*}{ Ascorbic acid $\left(\mathrm{mg} 100 \mathrm{~mL}^{-1}\right)$} & $71.5 \pm 0.71$ & $68.5 \pm 1.44$ \\
\hline & \multicolumn{2}{|c|}{ 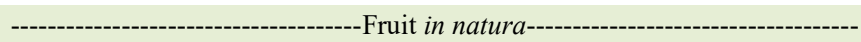 } \\
\hline $\mathrm{pH}$ & \multicolumn{2}{|c|}{$3.20 \pm 0.15$} \\
\hline Soluble solids ( ${ }^{\circ}$ Brix) & \multicolumn{2}{|c|}{$11.25 \pm 0.87$} \\
\hline Acidity (g citric acid $100 \mathrm{~mL}^{-1}$ ) & \multicolumn{2}{|c|}{$2.35 \pm 0.31$} \\
\hline Ascorbic acid $\left({\left.\mathrm{mg} 100 \mathrm{~mL}^{-1}\right)}^{\prime}\right.$ & \multicolumn{2}{|c|}{$143.43 \pm 10.67$} \\
\hline \multirow[t]{2}{*}{ Physical-chemical evaluations } & \multicolumn{2}{|c|}{ 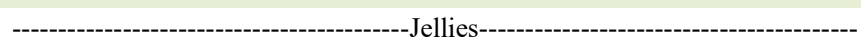 } \\
\hline & A & B \\
\hline Humidity (g 100g $\left.\mathrm{g}^{-1}\right)$ & 22.00 & 23.01 \\
\hline Reducing sugars $\left({\left.\mathrm{g} 100 \mathrm{~g}^{-1}\right)}^{-1}\right.$ & 63.24 & 62.30 \\
\hline
\end{tabular}

Ciência Rural, v.51, n.1, 2021. 
reduction of values from jam $\mathrm{A}$ to $\mathrm{B}$. This reduction occurred because jam B has a reduction of the sugar/ pulp ratio, this ratio being inversely proportional to the amount of vitamin $\mathrm{C}$ reported in it. Regarding the fruits, a greater was observed than the one found in the jams. This occurs, due to the cooking process of the jams, where high temperatures are the predominant factor in anaerobic degradation of ascorbic acid (LEMOS et al. 2019; ROTILI et al. 2018).

With this research it is possible to state that both fruits in natura and dovyalis jams are sources of vitamin $\mathrm{C}$, thus emphasizing their nutritional aspects, since, in Brazil, the daily recommended intake (RDI) for adults starts at $60 \mathrm{mg}$ (BRASIL, 1998).

The humidity in the jams varied between 22 and $23 \%$ (Table 1), recommended by the Brazilian Legislation (BRASIL, 1978), which determines a maximum limit for the jam from 35 to $38 \%$. The decrease in the fruit's activity and water contributes to its conservation, being an important information in the processing and storage of food. When a material is exposed to a certain moisture, it loses or gains water to adjust its own humidity to a condition of balance with the environment (ANDRADE et al. 2011).

Table 1 also shows the values for the reducing sugar contents of jams A and B, with 63.24

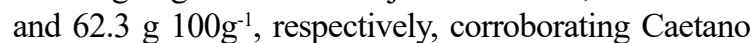
et al. (2012), where values of $62.3 \%$ were reported in the jam prepared from acerola fruits. In the jam, the highest contents of reducing sugars in jam A may be related to the inversion of sucrose during the cooking process.

The average values of the colorimetric analysis of jams A and B are shown in Figure 1. The brightness is the quality that characterizes the degree of color clarity, indicating whether the colors are light or dark $\left(\mathrm{L}^{*}=0\right.$, black to 100 , white) (PEREIRA et al. 2017; RAMOS \& GOMIDE, 2007).
The luminosity values ranged from 23.53 to 25.57 for jam A and B; respectively, thus demonstrating that the lower the value of $\mathrm{L}$, the darker the sample, indicating that jam A presented a lower value, due to the higher addition of sugar. In the research developed by Tanwar et al. (2014), guava jams showed values of $\mathrm{L}$.

Color parameter a (+) indicates the presence of the red color component in the jams, and, in this research, they ranged from 2.64 to 8.27 (Figure 1 ), with the highest value detected in jam B. It was verified that the sugar content directly influenced the intensity of reds of the respective jams, and the highest values of $+\mathrm{a}^{*}$ were reported in the jam formulated with smaller amounts of sugar, i.e., in jam B. Color b $(+)$; however, indicated the presence of the yellow component, which varied between 0.66 and 1.37 (Figure 1). Considering these values, it can be affirmed that, in the formulations of the jams, there was a greater presence of the red color components than those of yellow color, which can be attributed to the degradation of carotenoids responsible for the yellow coloration (MESQUITA et al. 2013).

The 30 judges who participated in the sensory analysis presented $50 \%$ of the masculine gender and $50 \%$ of the feminine gender as a profile, with ages between 19 and 60, different schooling and with jam consumption frequency of one to three times a week. Results of the sensory analysis of the jams (or acceptance of the products) are show in figure 2 .

A good acceptance of jams A and B was verified in the sensory analysis performed with the public, where the great majority presented attributes from numbers 5 to 8 , from slightly liked it to extremely liked it, with jam B being indicated

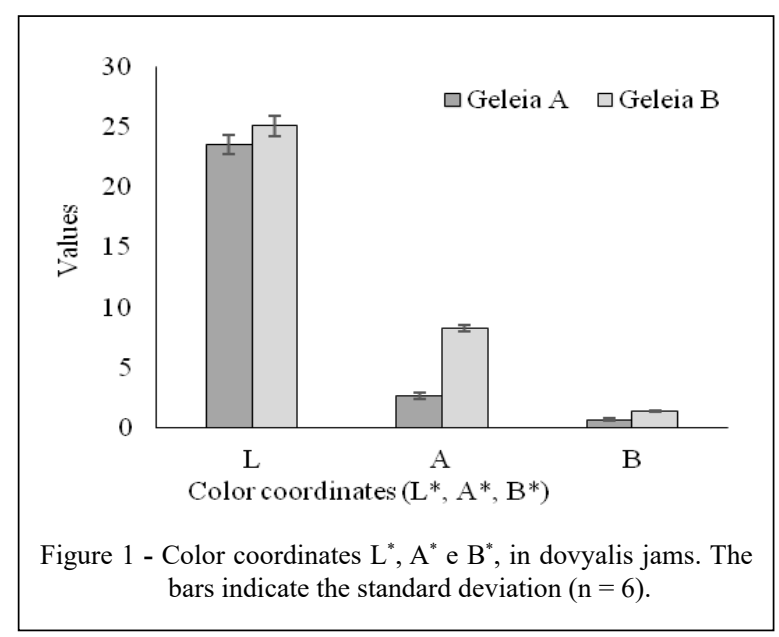

Ciência Rural, v.51, n.1, 2021. 


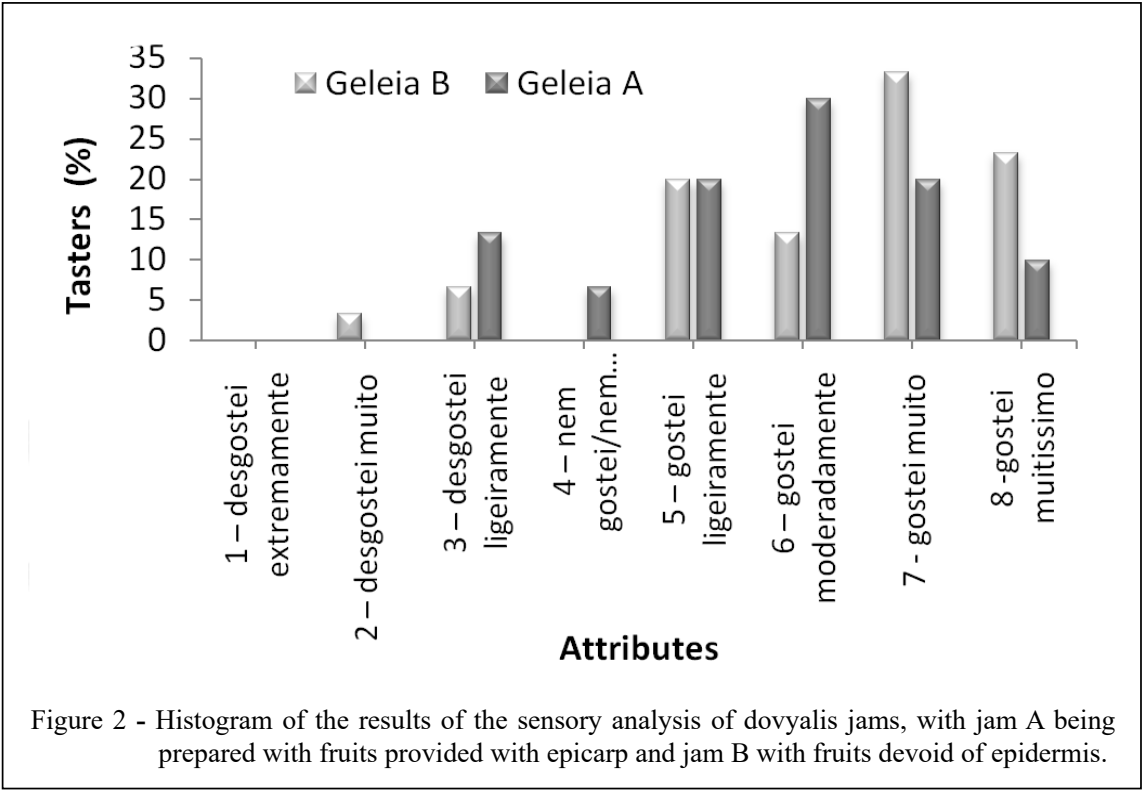

as the most accepted. According to Damiani et al. (2012) the evaluation of mango jams with pulp levels replacement by peels concluded that the products presented high acceptability among consumers.

Results of the purchase intent regarding the products are shown in figure 3 . Regarding the participants' purchase intention, they confirmed attribute 5, i.e., that they would buy the products. Among the preparation forms of the jam, the one prepared from fruits devoid of epicarp and endocarp and with less sugar was considered a better option for the judges.

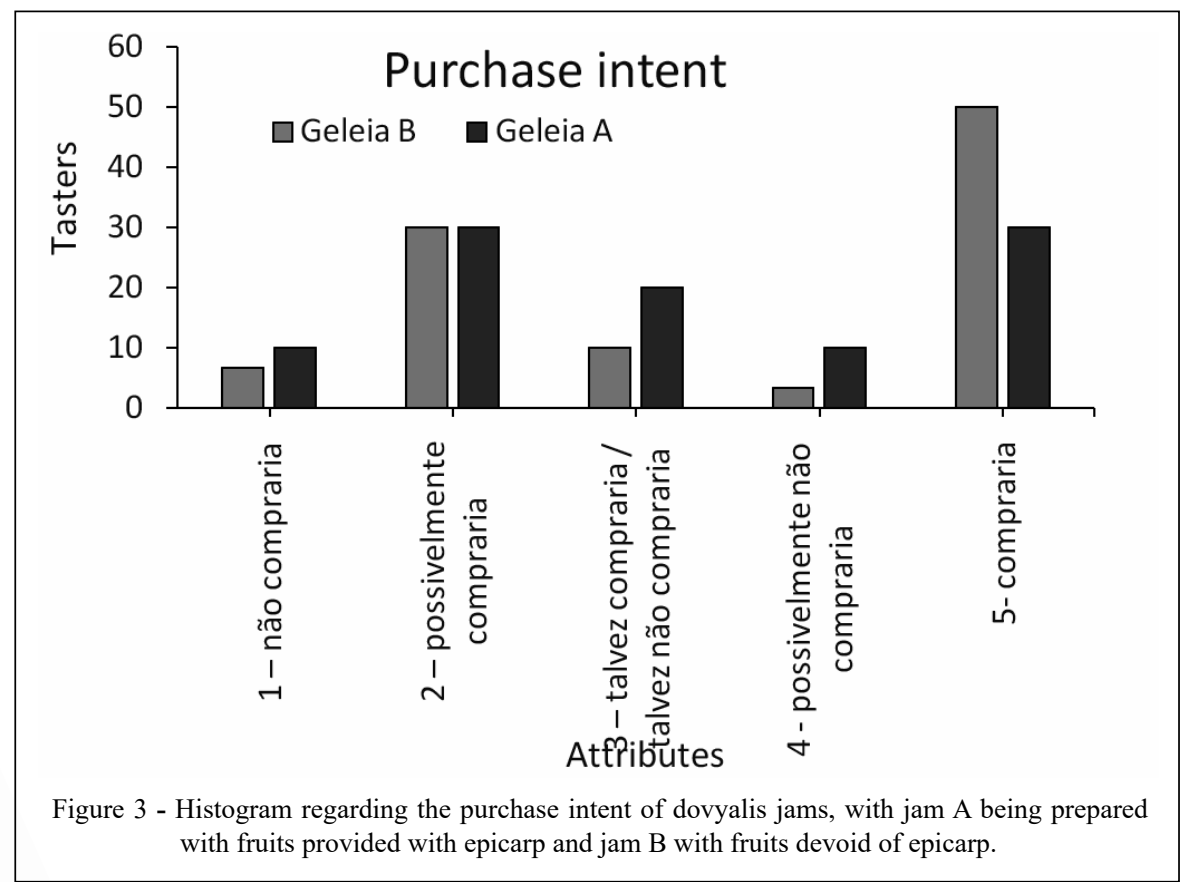

Ciência Rural, v.51, n.1, 2021. 
In the sensory analysis of physalis jam, the consumption and/or purchase intent was excellent (AVILA \& STORCK, 2014), indicating; therefore, that small fruits can be used in the processing, for example, in jams, being approved by the consumer. Future researches should be elaborated, because literature is scarce. For future studies, we suggested the use of sugar quantities, mixtures of dovyalis with other fruits and others formulations, in order to improve the appearance of the jam regarding cooking time.

\section{CONCLUSION}

The dovyalis jam; therefore, becomes another option to process this fruit with a tendency to enter the market, being well accepted by the consumer public. In natura fruits and dovyalis jams are sources of vitamin C. Sugar was the factor that most influenced the physical and chemical parameters analyzed.

In the sensory analysis, the judges liked both dovyalis jams. The jam prepared with dovyalis fruits without epicarp and endocarp, and less sugar, was more appreciated by the tasters in the sensory analysis.

\section{ACKNOWLEDGMENTS}

This study was financed in part by the Coordenação de Aperfeiçoamento de Pessoal de Nível Superior (CAPES), Brazil il, Finance code 001 .

\section{DECLARATION OF CONFLICTS OF INTERESTS}

The authors declare no conflict of interest. The founding sponsors had no role in the design of the study; in the collection, analyses, or interpretation of data; in the writing of the manuscript, and in the decision to publish the results.

\section{AUTHORS' CONTRIBUTIONS}

All authors contributed equally for the conception and writing of the manuscript. All authors critically revised the manuscript and approved of the final version.

\section{REFERENCES}

ALMEIDA, E.J. et al. Phenology of Dovyalis flowering and fruiting. Científica, v.39, [s.n.], p.79-84, 2011. Avaiable from: $<$ http://cientifica.org.br/index.php/cientifica/article/view/274>. Accessed: Apr. 06, 2020. doi: 10.15361/1984-5529.2011v39n1\% 2F2p79+-+84.

ANDRADE, P. et al. Models of sorption isotherms for food: uses and limitations. Vitae, v.18, p.325-334, 2011. Available from: $\quad<\mathrm{http}: / /$ www.scielo.org.co/scielo.php?script=sci arttext\&pid $=$ S0121-40042011000300012\&lng $=$ en\&nrm $=$ iso $>$. Accessed: Apr. 06, 2020.
AVILA, L.R.; STORCK, C.R. Preparation of traditional and diet Physalis jelly. Disciplinarum Scientia. Série: Ciências da Saúde, v.15, p.113-121 2014. Avaiable from: <https://periodicos.ufn.edu.br/index. php/disciplinarumS/article/view/1070>. Accessed: Apr. 06, 2020.

BENASSI, M.T.; ANTUNES, A.J. A comparison of metaphosphoric and oxalic acids as extract ant solutions for the determination of vitamin $\mathrm{C}$ in selected vegetables. Arquivos de Biologia e Tecnologia, v.31, [s.n.], p.507-513, 1988.

BORGES, G. et al. Identification of flavonoid and phenolic antioxidants in black currants, blueberries, raspberries, red currants, and cranberries. Journal of Agricultural and Food Chemistry, v.58, p.3901-3909, 2010. Avaiable from: <https:// www.researchgate.net/publication/40678737>. Accessed: Apr. 06, 2020. doi: $10.1021 / \mathrm{jf} 902263 \mathrm{n}$.

BRASIL. Portaria SVS/MS n³3. Tabelas de ingestão diária recomendada (IDR). Diário Oficial da União de 16 de janeiro de 1998. Avaiable from: <http://portal.anvisa.gov.br/ documents/33916/394219/Portaria_SVS_MS_33_de_janeiro_ de 1998.pdf/23279404-9b0e-4d69-8bfe-9a28e6e90b7e>. Accessed: Apr. 06, 2020.

CAETANO, P. K. et al. Caracterização físico-química e avaliação energética de geleia elaborada em diferentes tipos de tachos com polpa e suco de acerola. Revista Energia na Agricultura, v.26, n.2, p.103-118, 2011. Avaiable from: <http://revistas.fca.unesp.br/ index.php/energia/article/view/213>. Accessed: Apr. 06, 2020. doi: 10.17224/EnergAgric.2011v26n2p103-118.

CAETANO, P. K. et al. Característica físico-química e sensorial de geleia elaborada com polpa e suco de acerola. Brazilian Journal of Food Technology, v.15, p.191-197, 2012. Avaiable from: $<$ http://www.scielo.br/scielo.php?script=sci arttext\&pid=S1981$67232012000300002 \& \operatorname{lng}=$ en\&nrm=iso $>$. Accessed: Apr. 06, 2020. doi: 10.1590/S1981-67232012005000011.

CNNPA. COMISSÃO NACIONAL DE NORMAS E PADRÕES DE ALIMENTOS. Normas técnicas especiais. Resolução $\mathrm{n}^{\circ}$ 12/33. [Brasil]: D.O.U., 1978. Seção I, pt. I. Avaiable from: <http:// www.editoramagister.com/doc 308643 RESOLUCAO_N_12 DE MARCO DE 1978.aspx>. Accessed: Apr. 06, 2020.

CURI, P. N. et al. Processing potential of jellies from subtropical loquat cultivars. Food Science and Technology, v.37, p.7075, 2017. Available from: <http://www.scielo.br/scielo. php?script $=$ sci arttext\&pid $=$ S0101-20612017000100070\&lng $=$ en\&nrm=iso $>$. Accessed: Apr. 06, 2020. doi: 10.1590/1678$457 x .07216$

DAMIANI, C. et al. Antioxidant potential of Psidium guinnensis Sw. jam during storage. Pesquisa Agropecuária Tropical, v.42, [s.n.], p.90-98, 2012. Available from: <http://www.scielo.br/scielo. php? script=sci arttext\&pid=S1983-40632012000100013\&lng $=$ en\&nrm=iso $>$. Accessed: Apr. 06, 2020. doi: 10.1590/S198340632012000100013.

FERREIRA, D.F. Sisvar: a computer statistical analysis system. Ciência e Agrotecnologia, v.35, p.1039-1042,2011. Available from: $<\mathrm{http}: / /$ www.scielo.br/scielo.php?script=sci arttext\&pid=S141370542011000600001\&lng $=$ en\&nrm=iso $>$. Accessed: Apr. 06, 2020. doi: $10.1590 / \mathrm{S} 1413-70542011000600001$.

FERREIRA, R.M.A. et al. Qualidade sensorial de geleia mista de melancia e tamarindo. Revista Caatinga, v.24, n.2, p.202-206, 
2011. Available from: <file:///D:/Users/Usuario/Downloads/1706Artigo\%20de\%20submiss\%C3\%A3o-6204-1-10-20110106.pdf>. Accessed: Apr. 06, 2020.

IAL. INSTITUTO ADOLFO LUTZ. Normas analíticas do Instituto Adolfo Lutz: métodos químicos e físicos para análise de alimentos. 5a.ed. Instituto Adolfo Lutz, São Paulo, Brasil. 2008.

JACQUES, A.C.; ZAMBIAZI, C. Fitoquímicos em amora-preta (Rubus spp.). Semina: Ciências Agrárias, v.32, p.245-260, 2011. Avaiable from: <file:///D:/Users/Usuario/Downloads/4064-300571-PB.pdf $>$. Accessed: Apr. 06, 2020.

KEMP, S.E. et al. Sensory evaluation: a pratical handbook. Oxford: Willey-Blackwell. 2009. 196p.

LEMOS, D.M. et al. Elaboration and characterization of jabuticaba and acerola prebiotic jelly. Brazilian Journal of Food Technology, v.22, e2018098, 2019. Avaiable from: <https://www.scielo.br/pdf/ bjft/v22/1981-6723-bjft-22-e2018098.pdf $>$. Accessed: Apr. 06, 2020. doi: $10.1590 / 1981-6723.09818$.

MACIEL, M.I.S. et al. Características sensoriais e físico-químicas de geleias mistas de manga e acerola. Boletim Centro de Pesquisa de Processamento de Alimentos, v.27, [s.n.], p.247-256, 2009. Avaiable from: <https://revistas.ufpr.br/alimentos/article view/22035/14400>. Accessed: Apr. 06, 2020. doi: 10.1590/ S1981-67232012005000011.

MAIA, J.D. et al. Desenvolvimento, avaliação físico-química, microbiológica e sensorial de geleia de tamarindo. Revista GEINTEC, v.4, n.1, p.632-641, 2014. Avaiable from: <http:// www.revistageintec.net/index.php/revista/article/view/264/385>. Accessed: Apr. 06, 2020. doi: 10.7198/S2237-0722201400010017.

MEILGAARD, M. et al. Sensory evaluation techiniques. 4a. ed. Boca Raton: CRC Press. 2007. 448p.

MESQUITA, K.S. et al. Quality alterations during storage of sugarfree guava jam with added prebiotics. Journal of Food Processing and Preservation, v.37, p.806-813, 2013. doi: 10.1111/j.17454549.2012.00703.x.

OANCEA, S.; CALIN, F. Changes in total phenolics and anthocyanins during blackberry, raspberry and cherry Jam. Processing and Storage, v.21, p.11232-11237, 2016. Avaiable from: <https://www.rombio.eu/vol21nr1/19A4.pdf $>$. Accessed: Apr. 06, 2020.

OLIVEIRA, E.N.A. et al. Sensory profile of traditional jellies of Umbu-Caja. Bioscience Journal, v.29, supplement 1, p.1566-1575, 2013. Avaiable from: <file://D:/Users/Usuario/ Downloads/17244-Article\%20Text-93847-1-10-20131111.pdf>. Accessed: Apr. 06, 2020

PEREIRA, G.G. et al. Sensory evaluation of japanese quince jam with different concentrations of total soluble solids. Brazilian Journal of Food Technology, v.14, n.3, p.226-231, 2011. Avaiable from: <https://www.scielo.br/pdf/bjft/v14n3/07.pdf $>$. Accessed: Apr. 06, 2020. doi: 10.4260/BJFT2011140300027.

PEREIRA, J.M. et al. Elaboração e avaliação de geleia mista de caqui e morango. Tecnologia \& Ciência Agropecuária, v.11, n.6, p.101-105, 2017. Avaiable from: <https://revistatca.pb.gov. br/edicoes/volume-11-2017/v-11-n-6-dezembro-2017/13-artigo- ce-0917-05-elaboracao-e-avaliacao-de-geleia-mista-de-caqui-emorango.pdf $>$. Accessed: Apr. 06, 2020.

RAMOS, E.M.; GOMIDE, L.A.M. Avaliação objetiva da cor. In: avaliação da qualidade de carnes: fundamentos e metodologias. Cap. 7. Ed. UFV: Viçosa, 2007. p.287-370. Stem cuttings and substrates in Dovyalis asexual propagation.

RINALDI, A.R. et al. Stem cuttings and substrates in Dovyalis asexual propagation. Comunicata Scientiae, v.8, n.4, p.587595, 2017. Available from: <https://comunicatascientiae.com.br/ comunicata/article/view/1986>. Accessed: Apr. 06, 2020. doi: $10.14295 /$ cs.v8i4.1986

RODRIGUES, I.C. et al. Study of processing of watermelon jam enriched with jabuticaba extracts and chia seed extract: physicochemical characteristics and antioxidant potential. Research, Society and Development, v.9, n.5, e45952934, 2020. Available at: $\quad<$ https://rsd.unifei.edu.br/index.php/rsd/article/view/2934>. Accessed: Apr. 06, 2020. doi: 10.33448/rsd-v9i5.2934.

ROTILI, M.C.C. et al. Bioactive compounds, antioxidant and physic-chemical characteristics of the dovyalis fruit. Acta Scientiarum. Agronomy, v.40, e35465, 2018. Available from $<$ http://www.scielo.br/scielo.php?script=sci_arttext\&pid $=\mathrm{S} 1807$ $86212018000100613 \& \operatorname{lng}=$ en $\& n r m=$ iso $>$. Accessed: Apr. 06, 2020. doi: 10.4025/actasciagron.v40i1.35465.

SANTOS, M.S. et al. Chemical characterization and evaluation of the antioxidant potential of gabiroba jam (Campomanesia xanthocarpa Berg). Acta Scientiarum. Agronomy, v.35, p.73-82, 2013. Available from: <http://www.scielo.br/scielo. php?script $=$ sci arttext\&pid $=$ S1807-86212013000100009\&lng=en \&nrm=iso >. Accessed: Apr. 06, 2020. doi: 10.4025/actasciagron. v35il.14389.

SILVA, J.A.A. et al. Caracterização físico-química de frutos de clones de doviális (Dovyalis abyssinica warb). Revista Brasileira de Fruticultura, v. esp. 466-472, 2011. Available from: <http:// www.scielo.br/scielo.php? script $=$ sci_arttext\&pid $=\mathrm{S} 0100$ 29452011000500062\&lng=en\&nrm=iso >. Accessed: Apr. 06, 2020. doi: 10.1590/S0100-29452011000500062.

SOUZA, V.R. et al. Analysis of the subtropical blackberry cultivar potential in jelly processing. Journal of Food Science, v.79, p.1776-1781, 2014. doi: 10.1111/1750-3841.12565.

SOUZA, V.R. et al. Influence of processing on the antioxidant capacity and bioactive compounds in jellies from different blackberry cultivars. Journal of Food Science and Technology, v.50, n.9, p.1658-1665, 2015. doi: http://dx.doi.org/10.1111/ ijfs. 12819 .

TANWAR, B. et al. Influence of processing on physicochemical and nutritional composition of Psidium guajava L. (guava) products. International Journal of Agriculture and Food Science Technology, v.5, p.47-54, 2014.

TEIXEIRA, L.V. Análise sensorial na indústria de alimentos. Revista do Instituto de Laticínios Cândido Tostes, 64, 12-21, 2009.

ZORZI, M. et al. Bioactive compounds and antioxidant capacity of small berries. Foods, v.9, n.623, 2020. Avaiable from: <file:///D:/ Users/Usuario/Downloads/foods-09-00623.pdf>. Accessed: Apr. 06, 2020. doi: 10.3390/foods 9050623 . 